\title{
Kinetika Adsorpsi Zat Warna Tartrazina Menggunakan Limbah Ampas Tahu sebagai Adsorben
}

\author{
Matheis F.J.D.P. Tanasale ${ }^{* a}$, Yusthinus T. Male ${ }^{a}$, Nina B. Garium ${ }^{b}$ \\ a Jurusan Kimia, Fakultas Matematika dan Ilmu Pengetahuan Alam, Universitas Pattimura, Ambon 97234 \\ ${ }^{b}$ Laboratorium Kimia Fisika, Jurusan Kimia, Fakultas Matematika dan Ilmu Pengetahuan Alam, Universitas Pattimura, Ambon 97234
}

INFO ARTIKEL

\begin{tabular}{l}
\hline Diterima 25 Juni 2020 \\
Disetujui 26 Oktober 2020 \\
\hline Key word: \\
Kinetics of adsorption \\
Tartrazine \\
Waste of tofu \\
\hline Kata kunci: \\
Kinetika adsorpsi \\
Tartrazina \\
Limbah ampas tahu
\end{tabular}

${ }^{*} e$-mail:

mtanasale@fmipa.unpatti.ac.id

\begin{abstract}
A B S T R A C T
It has been conducted a research about the utilization waste of tofu as adsorbent of tartrazine dye. Utilization waste of tofu as adsorption because tofu contains protein which has the power adsorption of amino acids that form a zwitter ion. The purpose of this study was to determine the adsorption process and adosrption kinetics model of tartrazine dye by waste of tofu as adsorbent. Making the adsorbent is done by making waste of tofu into powder with a size of 100 mesh. The method used in the analysis of tartrazine dye is using UV-Vis. Adsorption of of tartrazine dye using waste of tofu at concentrations of $50 \mathrm{ppm}$ and a contact time of 80 minutes with weight adsorbent $0.3 \mathrm{~g}$. The two isotherms were used that Langmuir isotherm and Freundlich isotherm, the adsorption studies of tartrazine dye adsorbent waste of tofu follow Freundlich adsorption isotherms with a correlation coefficient $\left(R^{2}\right)$ of $94.4 \%, K_{F}$ is $0.0026 \mathrm{mg} / \mathrm{g}$ and $n$ is 0.5621 . Adsorption kinetics of of tartrazine dye adsorbent waste of tofu following the model of adsorption Ho pseudo-second order with a correlation coefficient $\left(R^{2}\right)$ of $100 \%, X_{e}$ is $1.7761 \mathrm{mg} / \mathrm{g}$ and $\mathrm{k}_{2, a d s}$ is $-0.6550 \mathrm{~g} / \mathrm{mg}$ minutes. The mechanism adsorption of of tartrazine dye with waste of tofu as adsorbent is chemisorpsi process.
\end{abstract}

\section{A BSTRAK}

Telah dilakukan penelitian pemanfaatan limbah ampas tahu sebagai adsorben untuk mengadsorpsi zat warna tartrazina. Pemanfaatan limbah ampas tahu ini sebagai pengadsorpsi karena tahu mengandung protein yang memiliki daya adsorpsi dari asam-asam amino yang membentuk ion zwitter. Tujuan dari penelitian ini adalah untuk menentukan proses adsorpsi dan model kinetika adsorpsi zat warna tartrazina oleh limbah ampas tahu sebagai adsorben. Pembuatan adsorben dilakukan dengan membuat limbah ampas tahu menjadi serbuk dengan ukuran 100 mesh. Metode yang digunakan dalam analisis zat warna tartrazina adalah menggunakan metode UV-Vis. Adsorpsi zat warna tartrazina menggunakan limbah ampas tahu terjadi pada konsentrasi 50 ppm dan waktu kontak 80 menit dengan jumlah adsorben 0,3 g. Dari kedua isoterm yang digunakan yaitu isoterm Langmuir dan isoterm Freundlich, dalam penelitian adsorpsi zat warna tartrazina oleh adsorben limbah ampas tahu mengikuti isoterm adsorpsi Freundlich dengan nilai koefisien korelasi $\left(R^{2}\right)$ 94,4\%, $K_{F}$ sebesar 0,0026 mg/g dan $n$ sebesar 0,5621. Kinetika adsorpsi zat warna tartrazina oleh adsorben limbah ampas tahu mengikuti model adsorpsi Ho orde dua-semu dengan nilai koefisien korelasi

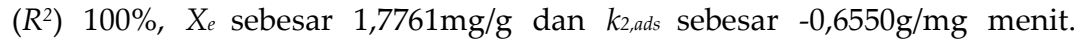
Mekanisme adsorpsi zat warna tartrazina oleh adsorben limbah ampas tahu adalah proses kimisorpsi.

\section{Pendahuluan}

Perkembangan ilmu teknologi dan berkembangnya dunia industri merupakan salah satu penyebab pencemaran lingkungan yang terjadi, 
baik terhadap manusia, tumbuhan maupun hewan. Industri tekstil merupakan satu dari sekian kegiatan industri yang cukup dominan berkembang di Indonesia. Salah satu yang perlu diperhatikan pada industri tekstil adalah limbah hasil produksinya dapat mencemari lingkungan khususnya pencemaran terhadap air. Limbah industri tekstil didominasi oleh pencemaran zat warna karena penggunaan zat warna baik yang alami maupun sintetis dalam proses produksinya. Pada proses pewarnaan tekstil berada dalam rentang 100 sampai 120 ppm sekitar $50 \%$ zat warna akan terserap dan sisanya akan didaur ulang atau dibuang sebagai limbah [1]. Apabila industri tekstil tersebut membuang limbah cairnya langsung ke selokan atau ke sungai, limbah cair ini dapat menurunkan daya pembersih alam yang dipunyai air, merubah warna air sungai, bahkan dapat mengakibatkan matinya organisme air yang penting artinya bagi kehidupan manusia.

Beberapa metode yang tersedia untuk menghilangkan warna dari air limbah seperti pemisahan membran, degradasi aerobik dan anaerobik, oksidasi kimia, koagulasi dan flokulasi, serta adsorpsi menggunakan berbagai jenis adsorben diantaranya, adsorpsi adalah teknik yang menjanjikan dan menghasilkan limbah yang mengandung tingkat yang sangat rendah dari senyawa organik terlarut. Penelitian yang cukup besar telah dilakukan dalam penghilangan zat warna dari teknik air limbah dengan menggunakan adsorben yang berbeda seperti karbon aktif, serbuk gergaji, tongkol jagung, kulit jeruk, biomasa mati atau hidup dan adsorben murah lainnya [2].

Senyawa alam yang banyak terdapat dalam limbah pertanian atau buangan industri merupakan potensi adsorben murah. Biaya pengolahan adalah parameter yang penting dalam memilih adsorben dan biaya masing-masing adsorben sangat bervariasi, tergantung pada proses yang diperlukan dalam ketersedian adsorben tersebut. Secara umum adsorben dapat dikatakan murah apabila tidak memerlukan atau memerlukan sedikit proses, bahannya banyak terdapat dan merupakan hasil samping atau limbah dari industri [3, 4].

Tatrazina (Gambar 1) merupakan zat warna azo yang cukup banyak digunakan dalam dunia industri, seperti bahan makanan, permen, obat-obatan, kosmetika, tekstil dan electroplating [5]. Beberapa masalah perikalu dapat terjadi akibat adanya tartrazina seperti alergi, reaksi penolakan racun, dan pemicuh sikap hiperaktif, serta penyebab beberapa penyakit seperti asma, migren, eksim, kanker tiroid dan lupus $[6,7]$.

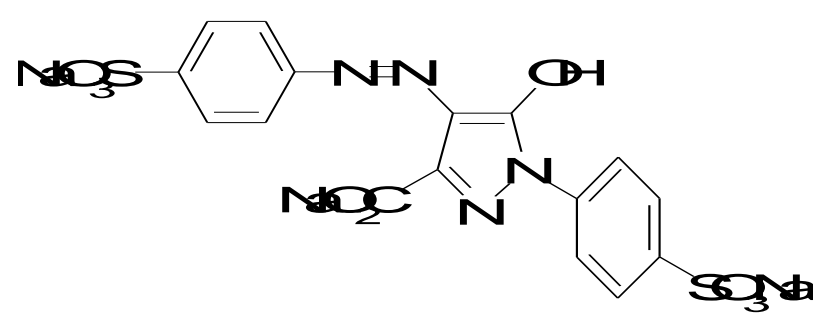

Gambar 1. Struktur molekul tartrazina

Kinetika adsorpsi zat warna tartrazina pada kitin dan kitosan optimum pada $\mathrm{pH}$ 9,0 dan mengikuti proses orde dua semu [8]. Kitosan berderajat deasetilasi tinggi juga telah digunakan sebagai adsorbent zat warna tartrazina, dengan hasil yang diperoleh yaitu mengikuti isoterm adsorpsi Freundlich dengan nilai $K_{F}$ sebesar 2,64 dan $n$ sebesar 0,84 serta model kinetika yang diikuti oleh adsorpsi zat warna tartrazina dengan kitosan adalah model kinetika orde dua semu dengan tetapan laju adsorpsi $\left(k_{2, a d s}\right)$ sebesar 0,052 $\mathrm{g} \mathrm{mg}^{-1}$ menit $^{-1}$ dan kapasitas adsorpsi maksimum adsorben $\left(X_{e}\right)$ sebesar $4,22 \mathrm{mg} g$ ${ }^{1}[9]$.

Pada penelitian ini digunakan metode adsorpsi karena banyaknya ketersediaan adsorben yang ada di alam dengan harga yang murah. Ada beberapa material yang biasanya digunakan sebagai adsorben seperti arang aktif, tanah diatomae, zeolit, bentonit, asam humat, pulp, dan silica. Salah satu hasil buangan yang berpotensi digunakan sebagai adsorben adalah limbah ampas tahu.

Pemanfaatan limbah tahu ini sebagai penyerap (pengadsorpsi) karena tahu mengandung protein yang memiliki daya serapan dari asam-asam amino yang membentuk zwitter ion (bermuatan dua). Protein yang memiliki sisi-sisi (gugus) aktif ini dapat mengikat ion-ion logam ataupun senyawa lainnya. Logam-logam berbahaya seperti kadmium, timbal, merkuri, krom dan arsen yang bersifat toksik dapat diikat dengan protein sebagai metalotionein [10]. Pemanfaatan limbah ampas tahu sebagai bahan penjerap logam $\mathrm{Cr}$, $\mathrm{Cd}$ dan $\mathrm{Fe}$ dalam air lindi TPA menunjukan hasil bahwa, kemampuan maksimum adsorben dari limbah ampas tahu mengadsorpsi krom dalam limbah air lindi TPA sebesar 100\% dan besi sebesar 95,53\%, sedangkan kemampuan maksimum limbah tahu dalam mengadsorpsi logam 
kadmiun tidak diperoleh [10]

Pada penelitian ini memanfaatkan limbah ampas tahu sebagai adsorben dalam menjerap zat warna tartrazina dan bertujuan untuk menentukan proses adsorpsi dan model kinetika adsorpsi zat warna tartarzina oleh limbah ampas tahu.

\section{Bahan dan Metode}

Bahan

Bahan-bahan yang digunakan dalam penelitian ini adalah limbah ampas tahu yang diambil dari industri tahu asal Kota Ambon, zat warna tartrazina, akuades, kertas saring, kalium hidrogen ftalat $0,1 \mathrm{M}$, $\mathrm{HCl}$ 0,1 M, $\mathrm{KH}_{2} \mathrm{PO}_{4}$ 0,1 M, NaOH 0,1 M, dan $\mathrm{NaHCO}_{3}$ $0,05 \mathrm{M}$.

\section{Prosedur Kerja}

Preparasi adsorben ampas tahu

Preparasi adsorben sebanyak $1 \mathrm{~kg}$ limbah ampas tahu basah diangin-anginkan dalam ruangan. Selanjutnya, limbah ampas tahu dimasukkan ke dalam oven dan dipanaskan pada suhu $60^{\circ} \mathrm{C}$ selama 14 jam. Hasilnya sebanyak $250 \mathrm{~g}$ limbah ampas tahu kering yang dapat digunakan sebagai adsorben, kemudian dihaluskan menggunakan lumpang dan alu serta diayak dengan mengunakan ayakan 100 mesh hingga memperoleh ukuran yang seragam dan disimpan dalam wadah bertutup sehingga terhindar dari kontak dengan udara [10].

\section{Karakterisasi adsorben ampas tahu \\ Penentuan kadar air}

Sebanyak 2,0 gram adsorben dipanaskan pada suhu $110^{\circ} \mathrm{C}$ selama 2 jam, didinginkan dan ditimbang sampai diperoleh berat konstan.

\section{Penentuan gugus fungsi}

Penentuan gugus fungsi yang terdapat dalam adsorben dilakukan dengan menggunakan spektrofotometer FTIR.

\section{Pembuatan larutan standar tartrazina}

Larutan standar tartrazina yang digunakan adalah 1, 2, 5, 10, 15, 20, 25, dan 30 ppm dan ditentukan absorbansi dengan spektrofotometer UVVis pada panjang gelombang $425 \mathrm{~nm}$ [9]

\section{Variasi pH optimum adsorpsi}

Disiapkan 3 buah erlenmeyer yang diisi larutan dengan variasi (a) $\mathrm{pH}=3$, (b) $\mathrm{pH}=7$, (c) $\mathrm{pH}=11$ yang diatur dengan menggunakan buffer. Buffer yang digunakan untuk variasi $\mathrm{pH}$ berturut-turut yaitu : (a) $50 \mathrm{~mL}$ kalium hidrogen ftalat $0,1 \mathrm{M} ; 22,3 \mathrm{~mL} \mathrm{HCl} 0,1$ $\mathrm{M}$ dan $22,7 \mathrm{~mL}$ akuades, (b) $50 \mathrm{~mL}$ larutan $\mathrm{KH}_{2} \mathrm{PO}_{4}$ 0,1 M; akuades 20,9 mL dan 29,1 mL NaOH 0,1 M dan (c) $50 \mathrm{~mL}$ larutan $\mathrm{NaHCO}_{3}$ 0,05 M; 27,3 mL akuades dan 22,7 $\mathrm{mL} \mathrm{NaOH} \mathrm{0,1} \mathrm{M}$ dengan volume akhir masing-masing larutan buffer $=100 \mathrm{~mL}$. Selanjutnya ditambahkan $25 \mathrm{~mL}$ larutan tartrazina dengan konsentrasi 20 ppm, kemudian larutan disheaker selama 1 jam dan disaring dengan kertas saring. Filtrat yang diperoleh diukur absorbansinya dengan spektrofotometer UV-Vis [9].

\section{Variasi jumlah adsorben}

Serbuk ampas tahu yang dijadikan sebagai adsorben masing-masing ditimbang sebanyak 0,2; 0,3; 0,4; 0,5 dan 1,0 g; dimasukkan ke dalam 5 buah erlenmeyer yang berisi $25 \mathrm{~mL}$ larutan tartrazina dengan konsentrasi $20 \mathrm{ppm}$ pada $\mathrm{pH}$ optimum yang diperoleh, selanjutnya larutan dishaker selama 1 jam, kemudian disaring. Filtrat yang diperoleh dianalisis dengan spektrofotometer UV-Vis pada panjang gelombang $425 \mathrm{~nm}$ [9].

\section{Variasi waktu optimum adsorpsi}

Serbuk tahu yang mempunyai jumlah adsorben optimum dimasukkan ke dalam 5 buah erlenmeyer yang berisi larutan $25 \mathrm{~mL}$ larutan zat tartrazina dengan konsentrasi $20 \mathrm{ppm}$ pada $\mathrm{pH}$ optimum yang diperoleh, selanjutnya larutan dishaker dengan variasi waktu kontak masing-masing 20, 40, 60, 80, dan 100 menit, kemudian disaring. Filtrat yang diperoleh dianalisis dengan spektrofotometer UV-Vis pada panjang gelombang $425 \mathrm{~nm}$ [9].

\section{Variasi konsentrasi zat warna tartrazina}

Sebanyak 5 buah erlenmeyer $100 \mathrm{~mL}$ disiapkan dan dimasukkan serbuk ampas tahu sebanyak adsorben optimum ke dalam masing-masing erlenmeyer, kemudian ditambahkan $25 \mathrm{~mL}$ larutan zat tartrazina dengan konsentrasi 10, 20, 30, 40, dan 50 ppm dengan $\mathrm{pH}$ optimum selanjutnya larutan dishaker selama waktu optimum dan disaring. Filtrat yang diperoleh kemudian dianalisis dengan menggunakan spektrofotometer UV-Vis pada panjang gelombang $425 \mathrm{~nm}$, selanjutnya dilakukan perhitungan untuk menentukan isoterm adsorpsi [9].

\section{Penentuan orde dan tetapan laju adsorpsi}

Untuk penentuan orde dan tetapan laju reaksi dilihat pada konsentrasi zat warna tartrazina 
optimum yang diperoleh dalam penelitian. Selanjutnya, campuran yang mempunyai adsorpsi optimum, diambil sebanyak $25 \mathrm{~mL}$, dimasukkan dalam erlenmeyer kemudian ditambahkan serbuk ampas tahu. Setelah itu dishaker selama 30 menit pada suhu $25^{\circ} \mathrm{C}$. Larutan yang dihasilkan, kemudian disaring dengan kertas saring. Selanjutnya ditentukan larutan setelah diadsorpsi dengan menggunakan spektrofotometer UV-Vis. Hal yang sama dilakukan untuk waktu 30, 60, 90, 120, dan 150 menit.

\section{Hasil dan Pembahasan}

Preparasi Adsorben Limbah Ampas Tahu

Hasil dari preparasi adsorben limbah ampas tahu yang didapat yaitu sebesar $250 \mathrm{~g}$ limbah ampas tahu kering dari $1 \mathrm{~kg}$ limbah ampas tahu. Ampas tahu kering yang diperoleh kemudian, dihaluskan hingga memperoleh ukuran yang seragam dan disimpan dalam wadah tertutup agar terhindar dari kontak dengan udara.

\section{Karakterisasi adsorben ampas tahu \\ Penentuan kadar air}

Pada umumnya, kadar air suatu bahan yang akan digunkan sebagai bahan adsorben maksimum sebesar $10 \%$, jika kadar air ampas tahu semakin banyak maka kemampuan adsorben untuk menjerap adsorbat akan semakin kecil karena molekul-molekul air menutupi pori-pori adsorben. Penentuan kadar air dilakukan secara gravimetri dengan cara mengeringkan bahan dalam oven pada suhu $110^{\circ} \mathrm{C}$ sampai diperoleh berat konsta. Pada penelitian diambil 2,0035 g adsorben ampas tahu kemudian dkeringkan dalam oven dengan menggunakan suhu $110{ }^{\circ} \mathrm{C}$ dan diperoleh kadar air sebesar 5,03\%. Hal ini menunjukkan bahwa ampas tahu mempunyai kemampuan sebagai adsorben.

\section{Penentuan gugus fungsi}

Penentuan gugus fungsi yang terdapat pada adsorben dilakaukan dengan menggunakan spektrofotometer FTIR. Spektrum FTIR adsorben limbah ampas tahu (Gambar 2) memperlihatkan beberapa pola serapan yaitu serapan yang muncul pada daerah $3336,85 \mathrm{~cm}^{-1}$ merupakan serapan dari gugus hidroksil $(-\mathrm{OH})$, serapan amin terdapat pada daerah $3282,84-3296,35 \mathrm{~cm}^{-1}$ berada pada posisi saling berhimpit dengan serapan -OH. Oleh karena amin ikatan hidrogen lebih lemah dan sebagian ikatan N-H kurang polar, maka serapannya kurang intensif dibandingkan dengan $-\mathrm{OH}$ dan daerah serapan dari C-H (stretching) berada pada daerah 28588,51-29299,87 $\mathrm{cm}^{-1}$. Serapan pada daerah $1635,64 \mathrm{~cm}^{-1}$ menunjukkan vibrasi ulur $\mathrm{C}=\mathrm{O}$ peptida adalah serapan karbonil. Serapan pada daerah 1371,39 merupakan daerah serapan vibrasi tekuk asam karboksilat, sedangkan pada daerah serapan $1047,35 \mathrm{~cm}^{-1}$ menunjukkan vibrasi $\mathrm{C}-\mathrm{O}$ dari asam karboksilat.

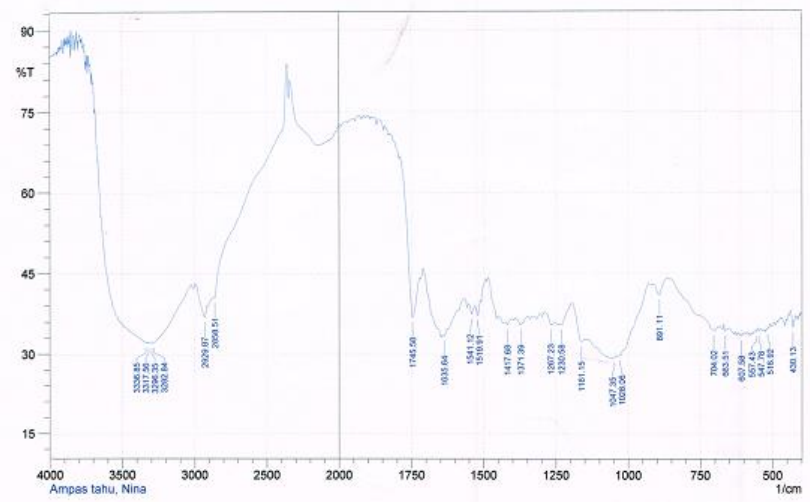

Gambar 2. Spektrum FTIR limbah ampas tahu

Beberapa gugus fungsi yang teridentifikasi dari spektrum FTIR limbah ampas tahu yang diperlihatkan pada Tabel 1 .

Tabel 1. Gugus fungsi yang teridentifikasi dari spektra FTIR adsorben ampas tahu

\begin{tabular}{cc}
\hline Gugus Fungsi & $\begin{array}{c}\text { Bilangan Gelombang } \\
\left(\mathrm{cm}^{-1}\right)\end{array}$ \\
\hline -OH & 3336,85 \\
N-H (stretching) & $3282,84-3296,35$ \\
C-H (alifatik) & $2858,51-2929,87$ \\
C=O & 1635,64 \\
$-\mathrm{OH}$ (vibrasi tekuk) & 1371,39 \\
C-O & 1047,35 \\
\hline
\end{tabular}

Proses Adsorpsi pada berbagai Variasi

Tabel 2. Absorbansi Larutan Standar Zat Warna

\begin{tabular}{cc}
\multicolumn{2}{c}{ Tartrazina } \\
\hline $\begin{array}{c}\text { Konsentrasi Zat Warna } \\
\text { Tartrazina }(\mathrm{ppm})\end{array}$ & Absorbansi \\
\hline 1 & 0,041 \\
2 & 0,072 \\
5 & 0,174 \\
10 & 0,353 \\
15 & 0,503 \\
20 & 0,693 \\
25 & 0,887 \\
30 & 1,189 \\
\hline
\end{tabular}


Sebelum dilakukan adsorpsi zat warna tartrazina pada berbagai variasi, larutan standar tartrazina terlebih dahulu diukur absorbansinya dengan menggunakan UV-Vis pada panjang gelombang $425 \mathrm{~nm}$ seperti terlihat pada Tabel 2.

\section{Proses Adsorpsi pada Variasi $p H$}

Sama halnya dengan studi kinetika zat warna tartrazina pada kitosan [11], kinetika adsorpsi zat warna tartrazina oleh limbah tahu sangat dipengaruhi oleh $\mathrm{pH}$ sehingga $\mathrm{pH}$ optimum sangat dipelukan. Nilai pH suatu larutan merupakan faktor penting untuk mengatur muatan pada permukaan adosrben dan derajat ionisasi dari adsorbat dalam larutan [5]. Hasil adsorpsi larutan zat warna tartrazina pada variasi $\mathrm{pH}$ optimum setelah pengukuran, diperoleh hasil seperti pada Tabel 3.

Tabel 3. Hasil pengukuran absorbansi zat warna tartrazina $\left(\mathrm{C}_{\mathrm{o}}=20 \mathrm{ppm}\right)$ pada variasi $\mathrm{pH}$ optimum

\begin{tabular}{ccccc}
\multicolumn{5}{c}{ adsorpsi } \\
\hline $\mathrm{pH}$ & Abs & $\begin{array}{c}\mathrm{C}_{0} \\
(\mathrm{ppm})\end{array}$ & $\begin{array}{c}\mathrm{C}_{e} \\
(\mathrm{ppm})\end{array}$ & $\begin{array}{c}\mathrm{C}_{0}-\mathrm{C}_{e} \\
(\mathrm{ppm})\end{array}$ \\
\hline 3 & 0,121 & 20 & 3,8018 & 16,1892 \\
7 & 0,115 & 20 & 3,6486 & 16,3114 \\
11 & 0,093 & 20 & 3,0540 & 16,9460 \\
\hline
\end{tabular}

Keterangan;

$C_{o}$ : konsentrasi adsorbat sebelum proses

adsorbsi

$C_{e}$ : konsentrasi adsorbat sesudah proses adsorpsi

$C_{o}-C_{e}:$ konsentrasi adsorbat yang terjerap

Pengukuran adsorbansi zat warna tartrazina pada variasi $\mathrm{pH}$ yaitu pada $\mathrm{pH}=3, \mathrm{pH}=7$, dan $\mathrm{pH}=$ 11 dengan konsentrasi awal zat warna tartrazina 20 ppm. Untuk mendapatkan kondisi larutan pada $\mathrm{pH}$ optimum dibutuhkan larutan buffer untuk tiga kondisi $\mathrm{pH}$ yaitu pada kondisi asam, netral dan basa. Setelah direaksikan maka konsentrasi zat warna tartrazina yang terjerap paling besar pada ketiga $\mathrm{pH}$ tersebut adalah larutan dalam suasana basa ( $\mathrm{pH} 11)$, jika dibandingkan dengan suasana asam ( $\mathrm{pH} 3)$ dan suasana netral ( $\mathrm{pH} 7$ ). Hasil ini bertentangan dengan teori yang menyebutkan bahwa pada suasana asam maka permukaan adsorben akan bermuatan positif dan mampu menjerap zat warna anionik seperti tartrazina [12]. Hal ini mungkin disebabkan karena sebagian limbah tahu akan larut pada suasana asam sehingga kemampuan adsorpsinya akan menurun jika dibandingkan dengan pada suasana basa. Kondisi yang sama juga diperoleh pada penelitian kami sebelumnya [11].
Proses Adsorpsi pada Variasi Jumlah Adsorben

Pada pengukuran absorbansi variasi jumlah adsorben serbuk ampas tahu dengan konsentrasi 20 ppm pada $\mathrm{pH} 11$ dan larutan yang diaduk dengan kecepatan 300 rpm selama 1 jam diperoleh hasil yang deperlihatkan pada Tabel 4.

Tabel 4. Hasil pengukuran absorbansi zat warna tartrazina $\left(\mathrm{C}_{\mathrm{o}}=20 \mathrm{ppm}\right)$ pada variasi jumlah adsorben

\begin{tabular}{cccc}
$\mathrm{m}(\mathrm{g})$ & $C_{o}(\mathrm{ppm})$ & $C_{e}(\mathrm{ppm})$ & $\mathrm{C}_{o}-C_{e}(\mathrm{ppm})$ \\
\hline 0,2 & 20 & 2,6216 & 17,3784 \\
0,3 & 20 & 2,0270 & 17,9730 \\
0,4 & 20 & 2,9729 & 17,0271 \\
0,5 & 20 & 3,4864 & 16,5136 \\
0,1 & 20 & 4,0810 & 15,9190 \\
\hline
\end{tabular}

Pada Tabel 4 memperlihatkan bahwa, pada bobot adsorben 0,2 g mampu menjerap konsentrasi tartrazina sebesar $17,9730 \mathrm{ppm}$, meningkat pada bobot adsorben 0,3 g yaitu 17,9730 ppm dan selanjutnya pada bobot adsorben $0,4 \mathrm{~g}, 0,5 \mathrm{~g}$, dan 1,0 $\mathrm{g}$ semakin menurun daya jerap adsorben. Hal ini disebabkan karena kemampuan adsorben mengalami kejenuhan, terjadi himpitan antara adsorben yang satu dengan adsorben yang lainnya sehingga daya adsorpsinya menurun [13]. Dari hasil tersebut pada bobot adsorben ampas tahu yang memiliki daya jerap optimum terhadap zat warna tartrazina dengan konsentrasi 20 ppm pada $\mathrm{pH} 11$ yaitu pada $0,3 \mathrm{~g}$.

\section{Proses Adsorpsi pada Variasi Waktu Kontak}

Penentuan waktu setimbang adsorpsi bertujuan untuk mengetahui waktu minimum yang dibutuhkan oleh adsorben dalam menjerap adsorbat secara maksimum hingga tercapai keadaan setimbang. Proses adsorpsi, berlangsung secara terus menerus selama belum terjadi kesetimbangan. Oleh karena itu, untuk mencari distribusi kesetimbangan antara adsorben dan adsorbat maka perlu menvariasikan waktu kontaknya [14].

Tabel 5. Hasil pengukuran absorbansi zat warna tartrazina $(\mathrm{Co}=20 \mathrm{ppm})$ pada variasi waktu kontak

\begin{tabular}{rrrr}
\hline $\begin{array}{c}\mathrm{t} \\
\text { (menit) }\end{array}$ & $\begin{array}{c}\mathrm{C}_{0} \\
(\mathrm{ppm})\end{array}$ & $\begin{array}{c}\mathrm{C}_{e} \\
(\mathrm{ppm})\end{array}$ & $\begin{array}{c}\mathrm{C}_{0}-\mathrm{C}_{e} \\
(\mathrm{ppm})\end{array}$ \\
\hline 20 & 20 & 19,4054 & 0,5946 \\
40 & 20 & 19,2162 & 0,7838 \\
60 & 20 & 19,4864 & 0,5136 \\
80 & 20 & 18,7297 & 1,2703 \\
100 & 20 & 19,1891 & 0,8109 \\
\hline
\end{tabular}


Pada variasi waktu kontak berturut-turut 20, 40, 60, 80, dan 100 menit untuk adsorpsi $25 \mathrm{ml}$ zat warna tartrazina 20 ppm dengan bobot adsorben $0,3 \mathrm{~g}$ yang dishaker dengan kecepatan 300 rpm, diperlihatkan pada Tabel 5 .

Besarnya konsentrasi yang terjerap juga sangat berpengaruh pada waktu adsorpsi atau waktu kontak antara zat warna tartrazina denagn adsorben limbah ampas tahu. Pada Tabel 5 diperlihatkan hasil bahwa pada waktu kontak 20-40 menit mengalami peningkatan adsorpsi, pada waktu kontak 60 menit mengalami penurunan, kemudian pada waktu kontak 80 menit kenaikan yang signifikan, dan pada waktu kontak 100 menit kembali mengalami penurunan. Dari hasil tersebut, pada waktu kontak 80 menit memiliki daya jerapnya lebih tinggi.

\section{Proses Adsorpsi pada Variasi Konsentrasi}

Adapun variasi konsentrasi yang digunakan pada penelitian ini adalah 10, 20, 30, 40, dan $50 \mathrm{ppm}$ dengan waktu kontak yang digunakan adalah 80 menit yang merupakan hasil dari penentuan waktu optimum untuk adsorpsi bobot adsorben 0,3 g dengan kecepatan pengadukan $300 \mathrm{rpm}$. Hasil penentuan konsentrasi optimum diperlihatkan pada Tabel 6.

Tabel 6. Konsentrasi adsorpsi oleh limbah ampas tahu pada berbagai variasi konsentrasi

\begin{tabular}{cccc}
\multicolumn{4}{c}{ adsorbat } \\
\hline$C_{o}(\mathrm{ppm})$ & $C_{e}(\mathrm{ppm})$ & $C_{0}-C_{e}(\mathrm{ppm})$ & $Q(\%)$ \\
\hline 10 & 8,7297 & 1,2703 & 12,70 \\
20 & 14,8108 & 5,1892 & 25,94 \\
30 & 21,7027 & 8,2973 & 27,57 \\
40 & 29,8918 & 10,1082 & 25,27 \\
50 & 32,5135 & 17,4865 & 34,97 \\
\hline
\end{tabular}

Keterangan;

$Q$ : presentase adsorpsi

Berdasarkan data hasil adsorpsi dengan variasi konsentrasi pada Tabel 6, maka konsentrasi maksimum teradsorpsi ada pada konsentrasi 50 ppm yang memiliki nilai $Q$ paling besar yaitu $34,97 \%$. Kapasitas adsorpsi meningkat seiring dengan meningkatnya konsentrasi awal dari adsorbat. Kapasitas adsorpsi maksimum diperoleh pada adsorpsi dengan konsentrasi awal adsorbat sebesar $50 \mathrm{ppm}$.

\section{Penentuan Isoterm Adsorpsi}

Aspek termodinamika adsorpsi membicarakan tentang kesetimbangan yang meliputi isoterm adsorpsi. Isoterm adsorpsi merupakan suatu gambaran tentang keadaan kesetimbangan yang telah terjadi sehingga tidak ada perubahan dalam konsentrasi adsorbat pada perrnukaan adsorben dan yang ada pada larutan ruah. Isoterm adsorpsi diperoleh dengan memetakan distribusi kesetimbangan adsorbat dalarn fase padat dan cair pada temperatur tetap. Parameter adsorpsi untuk kedua persamaan isoterm adsorpsi yang dapat digunakan untuk adsorpsi larutan pada permukaan padat yaitu isoterm adsorpsi Langmuir (Persamaan 1) dan isoterm adsorpsi Freundlich (Persamaan 2) diperlihatkan pada Tabel 7.

$$
\begin{aligned}
& \frac{\mathrm{c}_{\mathrm{e}}}{\mathrm{x} / \mathrm{m})}=\frac{1}{\mathrm{~K}_{\mathrm{L}}(\mathrm{x} / \mathrm{m})_{\text {max }}}+\frac{1}{(\mathrm{x} / \mathrm{m})_{\text {max }}} \mathrm{c}_{\mathrm{e}} \\
& \ln (\mathrm{x} / \mathrm{m})=\ln \mathrm{K}_{\mathrm{F}}+\frac{1}{\mathrm{n}} \ln \mathrm{c}_{\mathrm{e}}
\end{aligned}
$$

Tabel 7. Parameter adsorpsi adsorbat oleh limbah ampas tahu $(\mathrm{m}=0,3 \mathrm{~g})$ untuk isoterm adsorpsi Langmuir dan isoterm adsorpsi Freundlich

\begin{tabular}{ccccccc}
\hline $\begin{array}{c}C_{o} \\
(\mathrm{ppm})\end{array}$ & $\begin{array}{c}\mathrm{C}_{e} \\
(\mathrm{ppm})\end{array}$ & $\begin{array}{c}\mathrm{C}_{o}-C_{e} \\
(\mathrm{ppm})\end{array}$ & $x / m$ & $\begin{array}{c}C_{e} / \\
(x / m)\end{array}$ & $\begin{array}{c}\text { In } \\
C_{e}\end{array}$ & $\begin{array}{c}\text { In } \\
(x / m)\end{array}$ \\
\hline 10 & 8,72 & 1,27 & 0,10 & 82,51 & 2,16 & $-2,24$ \\
20 & 14,81 & 5,18 & 0,43 & 34,25 & 2,69 & $-0,83$ \\
30 & 21,70 & 8,29 & 0,69 & 31,38 & 3,07 & $-0,36$ \\
40 & 29,89 & 10,10 & 0,84 & 35,48 & 3,39 & $-0,17$ \\
50 & 32,51 & 17,48 & 1,45 & 22,31 & 3,48 & 0,37 \\
\hline
\end{tabular}

Keterangan:

$\mathrm{x} / \mathrm{m}$ : jumlah adsorbat $(\mathrm{mg})$ yang diserap dalam $m g$ adsorben yang diperoleh dari persamaan 3

$$
\frac{x}{m}=\frac{\left(C_{o}-C_{e}\right) x V(L)}{m(g)}
$$

Berdasarkan adsorpsi zat warna tartrazina oleh adsorben yaitu pada variasi konsentrasi maka dapat dibuat kurva isoterm adsorpsi. Adsorpsi larutan pada zat padat dapat mengikuti isoterm adsorpsi Langmuir atau Freundlich. Isoterm Langmuir berdasarkan hubungan $C_{e}$ terhadap $C_{e} /(x / m)$, sedangkan isoterm adsorpsi Freundlich berdasarkan hubungan $\ln C_{e}$ terhadap $\ln (x / m)$ dengan membandingkan kuadrat terkecil atau koefisien 
korelasi, maka dapat ditentukan isoterm apa yang sesuai [15] yang diperlihatkan pada Gambar 3 dan 4 .

Model isoterm adsorpsi Langmuir mengasumsikan permukaan adsorben mempunyai sejumlah tertentu situs adsorpsi yang sebanding dengan luas permukaan adsorben [16]. Masingmasing sisi aktif dari adsorben hanya dapat mengadsorpsi satu molekul adsorbat saja sehingga yang terbentuk adalah lapisan adsorpsi monolayer (lapisan tunggal).

Dari kurva isoterm adsorpsi berdasarkan variasi konsentrasi pada Gambar 3 dan 4, dapat ditentukan besarnya kemampuan penjerapan zat warna tartrazina oleh adsorben limbah ampas tahu berdasarkan garis lurus isoterm adsorpsi dengan melihat isoterm adsorpsi yang sesuai koefisien korelasinya $\left(R^{2}\right)$. Isoterm Langmuir yang menghubungkan $C_{e}$ vs $C_{e} /(x / m)$ memiliki nilai koefisien korelasi $\left(R^{2}\right)$ sebesar $61,0 \%$ sedangkan isoterm adsorpsi Freundlich yang menghubungkan $\ln C_{e}$ vs $\ln (x / m)$ memiliki nilai koefisien korelasi $\left(R^{2}\right)$ sebesar $94,4 \%$. Dari nilai-nilai koefisien korelasi maka nilai isoterm yang cocok untuk adsorpsi zat warna tartrazina oleh adsorben limbah ampas tahu, yaitu mengikuti isoterm adsorpsi Freundlich.

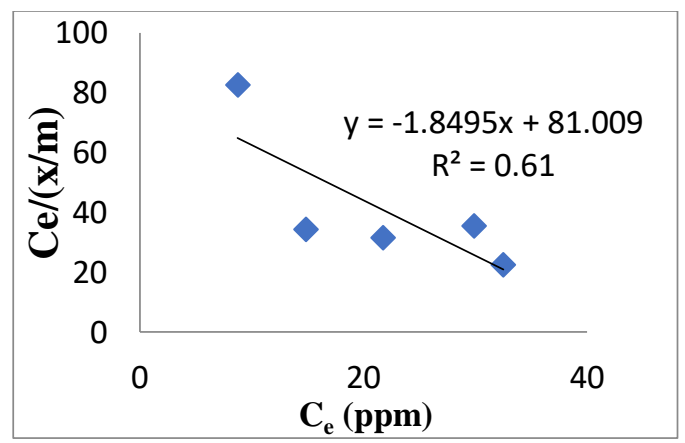

Gambar 3. Kurva isoterm adsorpsi Langmuir pada sistem adsorpsi zat warna tartrazina dengan adsorben limbah ampas tahu

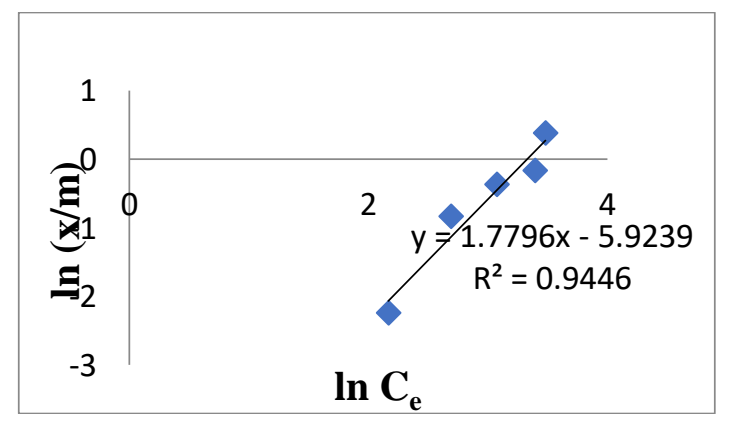

Gambar 4. Kurva isoterm adsorpsi Freundlich pada sistem adsorpsi zat warna tartrazina dengan adsorben limbah ampas tahu
Isoterm adsorpsi Langmuir hanya berlaku bagi adsorpsi lapisan tunggal pada permukaan adsorben yang bersifat homogen, sedangkan isoterm Freundlich diasumsikan bahwa adsorben mempunyai permukaan yang heterogen [17] dan tiap molekul mempunyai potensi penyerapan yang berbeda-beda, dengan beberapa tipe pusat adsorpsi yang aktif [15].

Hasil penelitian yang sama juga diperoleh pada adsorpsi logam kromium (Cr) oleh limbah ampas tahu yang mengikuti model isoterm adsorpsi Freundlich dengan nilai $R^{2}$ sebesar 88,1\% [18], sedangkan dalam penelitian ini, hasil yang diperoleh lebih besar yaitu mengikuti isoterm adsorpsi Freundlich dengan nilai $R^{2}$ sebesar $94,4 \%$. Hal ini membuktikan bahwa limbah ampas tahu dapat dijadikan adsorben dalam menjerap zat warna tartrazina, walaupun nilai $R^{2}$ yang diperoleh masih di bawah 95\%.

Tabel 8. Konsentrasi zat warna tartrazina yang telah teradsorpsi $\left(\mathrm{C}_{0}=50 \mathrm{ppm}\right)$ oleh adsorben limbah ampas tahu pada variasi waktu

\begin{tabular}{ccc}
\hline $\mathrm{t}$ (menit) & Abs & $C_{e}(\mathrm{ppm})$ \\
\hline 30 & 1,026 & 28,2702 \\
60 & 1,029 & 28,3113 \\
90 & 1,032 & 28,4324 \\
120 & 1,035 & 28,5135 \\
150 & 1,039 & 28,6216 \\
\hline
\end{tabular}

Berdasarkan kurva isoterm adsorpsi Freundlich, maka nilai $K_{F}$ dan $n$ dapat dihitung dengan menggunakan persamaan isoterm adsorpsi Freundlich sehingga diperoleh nilai $K_{F}$ sebesar 0,0026 $\mathrm{mg} / \mathrm{g}$ dan $n$ sebesar 0,5621 . Nilai $K_{F}$ menunjukkan kapasitas jerap suatu adsorben. Semakin besar nilai $K_{F}$ maka semakin besar pula kapasitas adsorben dalam menjerap adsorbat [17]. Nilai $1 / n$ menunjukkan indikator ketergantungan konsentrasi yang berhubungan dengan adsorpsi. Nilai $n$ menunjukkan derajat nonlinieritas antara konsentrasi larutan adsorpsi, yaitu mengukur penyimpangan linieritas adsorpsi dan biasanya digunakan untuk mengetahui tingkat kebenaran suatu adsorpsi. Dengan nilai $n<1$, maka dipastikan bahwa proses adsorpsi ini merupakan proses kimisorpsi dan jika $n$ $>1$, dipastikan bahwa adsorpsi yang terjadi merupakan proses fisisorpsi. Dengan demikian proses adsorpsi zat warna tartrazina oleh limbah ampas tahu dengan nilai $n$ sebesar 0,5621 merupakan 
proses kimisorpsi. Adsorpsi kimia atau kimisorpsi merupakan reaksi kimia antara padatan dengan larutan adsorbat yang bersifat tidak dapat balik, sedangkan adsorpsi fisik atau fisisorpsi terjadi terutama karena adanya ikatan Van Der Waals dan merupakan sejumlah kejadian yang dapat balik.

Tabel 9. Model kinetika adsorpsi Lagergren orde satu-semu zat warna tartrazina oleh adsorben limbah ampas tahu dengan konsentrasi mulamula 50 ppm

\begin{tabular}{lccc}
\hline \multirow{2}{*}{$\begin{array}{c}\text { Persamaan } \\
\text { Kinetika }\end{array}$} & $R^{2}$ & \multicolumn{2}{c}{$X_{e}(\mathrm{mg} / \mathrm{g})$} \\
\cline { 3 - 4 } & $(\%)$ & $\begin{array}{c}X_{e} \text { yang } \\
\text { dicoba }\end{array}$ & $\begin{array}{c}X_{e} \text { yang } \\
\text { dihitung }\end{array}$ \\
\hline $\ln \left(X_{e^{-}} X\right)=\ln X_{e}$ & & & \\
$-k_{1, \text { ads }}$ & 97,1 & 1,82 & 0,0072 \\
& 99,9 & 1,9 & 0,0832 \\
\hline
\end{tabular}

Orde dan Tetapan Laju Reaksi

Dalam menentukan orde dan tetapan laju adsorpsi digunakan konsentrasi tartrazina dan adsorben limbah ampas tahu yang mempunyai adsorpsi maksimum diperoleh pada Tabel 5 yaitu konsentrasi $50 \mathrm{ppm}$. Selanjutnya pengukuran dengan variasi waktu yaitu 30, 60, 90, 120, dan 150 menit yang dilihat pada Tabel 8 .

\section{Model Kinetika adsorpsi Lagergren Orde satu-semu}

Model kinetika adsorpsi Lagergren orde satusemu zat warna tartrazina oleh adsorben limbah ampas tahu pada konsentrasi 50 ppm dengan nilainilai parameter-parameter yang digunakan diperlihatkan pada Tabel 10.

Tabel 10. Parameter-parameter model kinetika adsorpsi Lagergren orde satu-semu zat warna tartrazina oleh adsorben limbah ampas tahu dengan konsentrasi mula-mula $50 \mathrm{ppm}$ dan nilai $X_{e}$ yang dicoba $=1,9 \mathrm{mg} / \mathrm{g}$

\begin{tabular}{cccccc}
\hline $\mathrm{t}$ (menit) & Abs & $\begin{array}{c}C_{e} \\
(\mathrm{ppm})\end{array}$ & $\begin{array}{c}x \\
(m g / g)\end{array}$ & $\mathrm{Xe}-x$ & $\ln \mathrm{Xe}-x$ \\
\hline 30 & 1,02 & 28,27 & 1,81 & 0,08 & $-2,41$ \\
60 & 1,02 & 28,31 & 1,80 & 0,09 & $-2,34$ \\
90 & 1,03 & 28,43 & 1,79 & 0,10 & $-2,27$ \\
120 & 1,03 & 28,51 & 1,79 & 0,11 & $-2,20$ \\
150 & 1,03 & 28,62 & 1,78 & 0,11 & $-2,13$ \\
\hline
\end{tabular}

Dari nilai parameter-parameter pada Tabel 9, dengan nilai $X_{e}$ yang dicoba $1,9 \mathrm{mg} / \mathrm{g}$ dan $X_{e}$ yang dicoba $1,82 \mathrm{mg} / \mathrm{g}$, hasil perhitungan diperlihatkan pada Tabel 9 dan dengan menggunakan data pada Tabel 10, maka dapat dibuat kurva $t$ vs $\ln \left(X_{e}-X\right)$ untuk model kinetika adsorpsi Lagergren orde satusemu seperti terlihat pada Gambar 5.

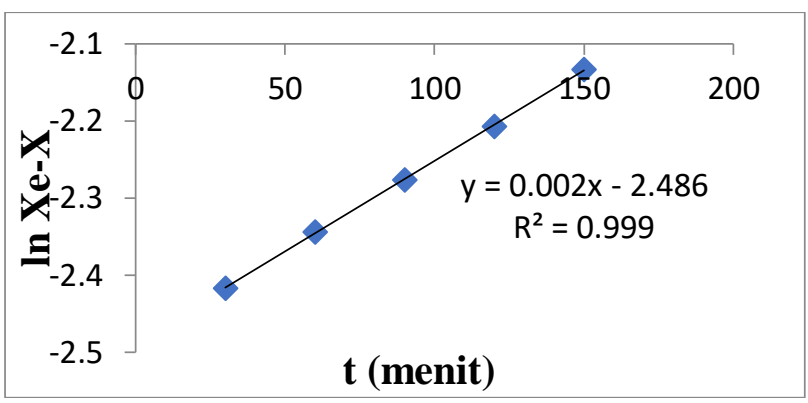

Gambar 5. Kurva kinetika adsorpsi Lagergren orde satu-semu

Nilai koefisien korelasi $\left(R^{2}\right)$ yang diperoleh dari kurva pada Gambar 5, pada kinetika adsorpsi zat warna tartrazina oleh adsorben limbah ampas tahu dengan konsentrasi 50 ppm sebesar 99,9\%. Dengan demikian tetapan laju adsorpsi orde satu-semu $\left(k_{1, a d s}\right)$ sebesar 2,0 x 10-3 menit ${ }^{-1}$ dan $X_{e}, h i t$ adalah $0,0832 \mathrm{mg} / \mathrm{g}$. Walaupun nilai $\mathrm{R}^{2}$ yang mendekati $100 \%$ tetapi karena perbedaan nilai $\mathrm{X}_{\mathrm{e}, \text { coba }}$ dengan $\mathrm{X}_{\mathrm{e}, \mathrm{hit}}$ sangat jauh berbeda maka kinetika adsorpsi zat warna tartrazina oleh limbah ampas tahu tidak mengikuti model kinetika adsorpsi Lagergren orde satu-semu.

\section{Model Kinetika adsorpsi Ho Orde dua-semu}

Pengolahan data hasil penjerapan model kinetika adsorpsi Ho orde dua-semu zat warna tartrazina oleh adsorben limbah ampas tahu pada konsentrasi 50 ppm dapat dilihat pada Tabel 11 dan Gambar 6 serta dengan menggunakan data pada Tabel 11, maka dapat dibuat kurva $t$ vs $t / X$ untuk model kinetika adsorpsi Ho orde dua-semu seperti terlihat pada Gambar 6.

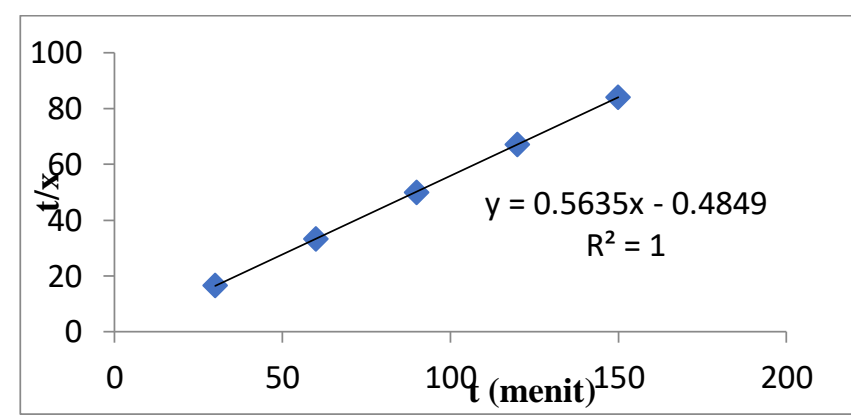

Gambar 6. Kurva kinetika adsorpsi Ho orde duasemu 
Tabel 11. Parameter-parameter model kinetika adsorpsi Ho orde dua-semu zat warna tartrazina oleh limbah ampas tahu pada konsentrasi mulamula 50 ppm

\begin{tabular}{cccccc}
\hline & Abs & $\begin{array}{c}C_{e} \\
(\mathrm{ppm})\end{array}$ & $\begin{array}{c}\mathrm{C}_{0}-\mathrm{C}_{e} \\
(\mathrm{ppm})\end{array}$ & $\begin{array}{c}x \\
(\mathrm{mg} / \mathrm{g})\end{array}$ & $\mathrm{t} / x$ \\
\hline 30 & 1,02 & 28,27 & 21,72 & 1,81 & 16,56 \\
60 & 1,02 & 28,31 & 21,64 & 1,80 & 33,25 \\
90 & 1,03 & 28,43 & 21,56 & 1,79 & 50,07 \\
120 & 1,03 & 28,51 & 21,48 & 1,79 & 67,03 \\
150 & 1,03 & 28,62 & 21,37 & 1,78 & 84,19 \\
\hline
\end{tabular}

Nilai koefisien korelasi $\left(R^{2}\right)$ yang diperoleh dari kurva pada Gambar 6, sebesar 100\%, lebih besar dibandingkan dengan nilai koefisien korelasi pada Gambar 5 untuk kurva kinetika adsorpsi Lagergren orde satu-semu. Hal ini berarti bahwa kinetika adsorpsi zat warna tartrazina oleh adsorben limbah ampas tahu dengan konsentrasi 50 ppm mengikuti model kinetika adsorpsi Ho orde dua-semu dengan nilai $X_{e}$ sebesar $1,7761 \mathrm{mg} / \mathrm{g}$ dan $k_{2, a d s}$ sebesar $-0,6550$ $\mathrm{g} / \mathrm{mg}$ menit.

Hasil yang sama juga diperoleh pada kinetika adsorpsi logam Cr oleh adsorben limbah ampas tahu yang mengikuti model kinetika adsorpsi Ho orde dua-semu dengan $R^{2}$ sebesar 99,4\% [18]. Nilai $k_{2, a d s}$ merupakan parameter kinetika adsorpsi yang memaknai cepat atau lambat suatu proses adsorpsi itu berlangsung, makin tinggi nilai $k_{2, a d s}$ makin cepat proses adsorpsi berlangsung. Nilai negatif pada tetapan laju adsorpsi model Ho orde dua-semua menunjukkan bahwa terjadi perlambatan dalam proses adsorpsi zat warna tartrazina oleh limbah ampas tahu. Hal ini mendukung apa yang diperoleh pada variasi waktu kontak yang memperlihatkan penurunan adsorptivitas pada waktu kontak 100 menit setelah mencapai keadaan optimum pada waktu kontak 80 menit (Tabel 5).

\section{Mekanisme Adsorpsi Zat Warna Tartrazina oleh Adsorben Limbah Ampas Tahu}

Mekanisme adsorpsi suatu larutan terdiri dari empat tahap yaitu (a) proses difusi zat terlarut dan fase ruah ke lapisan batas di sekitar partikel adsorben (difusi ruah), (b) proses difusi dan lapisan batas ke permukaan partikel adsorbent (difusi eksternal), (c) difusi dan permukaan ke sisi internal adsorbent (difusi permukaan atau difusi pori), dan (d) proses pengambilan yang terdiri dan penjerapan kimia-fisik, pertukaran ion, pengendapan atau pembentukan kompleks [19, 20]. Tahap (a), (b), dan (d) merupakan penentu laju proses adsorpsi sedangkan tahap (c) diasumsikan berjalan sangat cepat. Tahap mana yang menjadi penentu laju proses adsorpsi ini akan sangat tergantung dari orde reaksinya. Mekanisme proses adsorpsi terdapat pada tahap (d) dengan proses pengambilan yang berlangsung paling lambat.

Difusi intra partikel bergantung pada beberapa faktor seperti struktur sorben, sifat fisik sorben dan sorbat, sifat-sifat kimia sorbat, interaksi sistem, dan kondisi sistem. Mekanisme difusi intra partikel didasarkan pada dua mekanisme yaitu difusi pori dan difusi padat. Difusi pori bergantung pada transport pelarut dan struktur internal dari pori-pori adsorben. Mekanisme ini menjelaskan difusi molekul adsorbat ke dalam partikel dalam cairan dan dalam pori-pori cairan. Difusi padat dihasilkan oleh adsorpsi larutan awal pada permukaan homogen secara energetika. Homogenitas permukaan mengacu pada keseragaman struktur pori dalam adsorden yang akan mempengaruhi tingkat energi dan adsorpsi yang sama.

Dalam penelitian ini yaitu mengadsorpsi zat warna tartrazina menggunakan limbah ampas tahu sebagai adsorben merupakan adsorpsi kimia. Adsorpsi ini partikel melekat pada permukaan membentuk ikatan kimia (ikatan kovalen), dan memaksimumkan bilangan koordinasinya dengan substrat [15]. Adsorpsi ini bersifat ireversibel, diperlukan energi yang kuat untuk melepaskan kembali adsorbat karena berupa ikatan kimia yang sangat kuat. Zat teradsorpsi membentuk monomolekuler dan relatif lambat tercapai kesetimbangan karena dalam adsorpsi kimia melibatkan energi aktivasi [16].

\section{Kesimpulan}

Berdasarkan hasil penelitian, dapat disimpulkan bahwa Kondisi optimum adsorpsi adsorben limbah ampas tahu dalam menjerap zat warna tartrazina pada beberapa variasi yaitu $\mathrm{pH} 3$, jumlah adsorben 0,3 g, waktu 80 menit, dan konsentrasi $50 \mathrm{ppm}$. Isoterm adsorpsi yang diikuti oleh proses adsorpsi zat warna tartrazina oleh limbah ampas tahu adalah isoterm Freundlich dengan nilai $K_{F}$ adalah $0,0026 \mathrm{mg} / \mathrm{g}$ dan $n=0,5621$ yang menunjukkan terjadinya proses adsorpsi kimia (kimisorpsi) pada permukaan heterogen. Model kinetika adsorpsi zat warna tartrazina oleh adsorben limbah ampas tahu pada konsentrasi 50 ppm mengikuti model kinetika adsorpsi Ho orde duasemu dengan nilai koefisien korelasi $\left(R^{2}\right) 100 \%, X_{e}$ 
sebesar $1,7761 \mathrm{mg} / \mathrm{g}$, dan $k_{2, \text { ads }}$ sebesar $-0,6550 \mathrm{~g} / \mathrm{mg}$ menit.

\section{Daftar Pustaka}

1. Mulyatna, L., Pradiko, H., Nasution, U.K. Pemilihan Persamaan Adsorpsi Isoterm pada Penenetuan Kapasitas Adsorpsi Kulit Kacang Tanah terhadap Zat Warna Remazol Golden Yellow 6, INFOMATEK, 2003, 5, (3), 131 - 140

2. Chandra, T.C., Mirna, M.M., Sudaryanto, Y., Ismadji, S. Adsorption of Basic Dye onto Carbon prepared from Durian Shell: Studies of Adsorption Equilibrium and Kinetics. Chem. Eng. J. 2007, 127, (1), 121 -129, DOI: 10.1016/j.cej.2006.09.011

3. Crini, G. Non-conventional low cost adsorbents for dyes removal A review. Bioresour. Technol. 2006, 97, (9), 1061-1085, DOI: 10.1016/j.biortech.2005.05001

4. Rafatullah, M., Sulaiman, O., Hashim, R., Ahmad, A. Adsorption of methylene blue on low-cost adsorbents: a review. J. Hazard. Mater. 2010, 177, (1), 70-80, DOI: 10.1016/j.jhazmat.2009.12.047

5. Wan Ngah, W. S., Ariff, N. F. M., Hanafiah, M.A.K.M. Preparation, Characterization, and Environmental Application of Crosslinked Chitosan-Coated Bentonite for Tartrazine Adsorption from Aqueous Solutions Water Air Soil Pollut, 2010, 206, 225-236, DOI: $10.1007 / \mathrm{s} 11270-009-0098-5$

6. Dotto, G. L., Vieira, M. L. G., Pinto, L. A. A. Kinetics and Mechanism of Tartrazine Adsorption onto Chitin and Chitosan. Ind. Eng. Chem. Res. 2012,. 51, 6862-6868, DOI: 10.1021/ie2030757

7. Chung, K.-T. Azo dyes and human health: A review. Journal of Environmental Science and Health, Part C. 2016, 34, 233-361, DOI: 10.1080/10590501.2016.1236602

8. Tanasale, M. F. J. D. P., Kinetika Adsorpsi Zat Warna Tartrazina pada Kitin dan Kitosan, Prosiding Seminar Nasional Kimia XVIII, Jurusan Kimia FMIPA UGM, Yogyakarta, 2008

9. Tanasale, M.F.J.D.P., Tehubijuluw, H., Sekewael, S.J., Aplikasi kitosan berderajat deasetilasi tinggi sebagai adsorbent zat warna tartrazina, Prosiding Seminar Nasional Basic Science VI Tahun 2014 (ISBN: 978-602-97522-0-5), 2014, $229-237$

10. Nohong, Pemanfaatan Limbah Tahu sebagai Bahan Penyerap Logam Krom, Kadmium dan Besi dalam Air Lidi TPA. Jurnal Pembelajaran Sains, 2010, 6 (2), 257-269
11. Fransina, E.G., Tanasale, M.F.J.D.P., Adsorption Kinetics of Tartrazine on Chitosan: Comparison of Linear and Non-Linear Methods, Rasayan J. Chem., 2019, 12, (4), 2241 - 2251, DOI: 10.31788/RJC.2019.1245309

12. Kumar, M.N.V.R., A review of chitin and chitosan applications, Reactive \& Functional Polymers, 2000, 46, 1 - 27, DOI: 10.1016/S13815148(00)00038-9

13. Tanasale, M.F.J.D.P., Sutapa, I W., Topurtawy, R.R., Adsorpsi Zat Warna Rhodamin B oleh Karbon Aktif dari Kulit Durian (Durio zibethinus). Indo. J. Chem. Res., 2014, 2, (1), 116 121

14. Widihati, I. A. G., Suastuti, N. G. A. M. D. A., Nirmalasari M. A. Y., Studi Kinetika Adsorpsi Larutan Ion Logam Kromium (Cr) menggunakan Arang Batang Pisang (Musa paradisiaca). Jurnal Kimia, 2012, 6, (1), 8-16.

15. Atkins, P. W., Kimia Fisika, Jilid 1, Edisi keempat, Penerjemah: Irma I. Kartohadiprojo. Erlangga,. Jakarta, 1997,

16. Oscik, J., Adsorption Ellis Horwood Series in Physical Chemistry, Ellis Horwood Limited, 1982, ISBN: 978-0853121664

17. Lynam, M.M., Kilduff, J.E., Weber, W.J. Jr., Adsorption of p-nitrophenol from dilute aqueous solution. J.Chem.Edu., 1995, 72, 80 - 84, DOI: 10.1021/ed072p80

18. Rachman, R. Kinetika Adsorpsi Logam Kromium (Cr) menggunakan Limbah Ampas Tahu sebagai Adsorben (Skripsi), Universitas Pattimura, Ambon, 2017

19. Allen, S. J., Whitten, L. J., Murray, M., Duggan, O., Brown, P., The Adsorption of Pollutans by Peat, Lignite and Actived Chars, J. Chem Tech. Biotechnol, 1997, 68, 442-452, DOI: 10.1001/(SCI)1097-4660(199704)68:4<442::AIDJCTB643>3.0.CO;2-2

20. Guibal, E., Milot, C., Tobin, J.M. Metal-Anion Sorption by Chitosan Beads: Equilibrium and Kinetic Studies. Ind. Eng. Chem. Res. 1998, 37, (4), 1454 - 1463, DOI: 10.1021/ie9703954

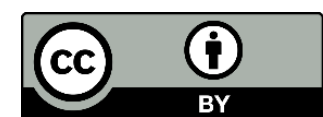

(C) 2020 by the authors. Licensee Fullerene Journal Of Chem. This article is an open access article distributed under the terms and conditions of the Creative Commons Attribution (CC BY) license (http://creativecommons.org/licenses/by/4.0/). 